\title{
Alec Patton
}

\section{Jazz and Music-Hall Transgressions in Theatre Workshop's Production of A Taste of Honey}

\begin{abstract}
Shelagh Delaney's A Taste of Honey in the Theatre Workshop production of 1959 opened to the sound of a fast twelve-bar blues played on trumpet, saxophone, and guitar by musicians sitting in a box to the right of the stage. Though rarely mentioned by historians, the 'Apex Jazz Trio', as they were called, were a lively and unpredictable element in the production. Between the actors' open acknowledgement of the band, and Avis Bunnage's direct comments to the audience, the play shattered the 'realistic' conventions that still held sway in the West End, at the same time transgressing the distinction between 'serious' theatre and music hall (where the boundary of the proscenium was never respected obsequiously). Alec Patton, a PhD student at the University of Sheffield, draws on original interviews with actors from the cast, a member of the first-night audience, and the leader of the band that accompanied the show to offer a re-assessment of the role of music and music hall in the original production of $A$ Taste of Honey.
\end{abstract}

THIS ARTICLE examines some of the ways that Joan Littlewood's Theatre Workshop incorporated jazz and elements from the British music hall into Shelagh Delaney's $A$ Taste of Honey (1959). It is based primarily on interviews with Murray Melvin ${ }^{1}$ and Frances $\mathrm{Cuka}^{2}$ who played two of the leading roles in the production; John Wallbank, ${ }^{3}$ a trumpet player who led the Apex Jazz Trio, the band that accompanied the show; and Jack Reading, ${ }^{4}$ founder and former Vice-President of the Society for Theatre Research, who attended the opening night.

I have written it as a response and, I hope, a contribution to Howard Goorney's work in The Theatre Workshop Story. ${ }^{5}$ Goorney was an actor in Theatre Workshop, and his book spans the company's entire history, blending personal reminiscence, archival research, and first-person interviews. Goorney is only able to describe each production briefly, and Joan Littlewood's autobiography also leaves many gaps in the history of A Taste of Honey. ${ }^{6}$ In this article I hope to fill a few of these gaps and discuss the significance of some of the production's extra-textual elements.

In the last chapter of The Theatre Workshop Story, Howard Goorney writes:
Singing, dancing, and the use of music as an integral part of a production was, before the war, generally confined to 'musicals'. That they are now freely accepted in 'straight' productions could well be attributed to Joan's work. ${ }^{7}$

Joan Littlewood's production of A Taste of Honey used jazz music and music-hall performance techniques to challenge and subvert naturalism. These led to generic transgression (adulterating a predominantly naturalistic play with musical comedy and music-hall techniques) and spatial transgression (breaking through the 'fourth wall' between actors and audience). Though A Taste of Honey is often remembered as a work of 'kitchen sink' realism (largely because of Tony Richardson's completely naturalistic film version) ${ }^{8}$ the Theatre Workshop production routinely subverted realism, paving the way for Workshop's later experiments in genre-crossing that culminated in Oh! What A Lovely War (1963).

The plot of $A$ Taste of Honey is very simple: a teenage girl, Jo, and her mother, Helen, move into a flat in a slum near the river in Salford, on the outskirts of Manchester. Helen's young boyfriend, Peter, finds them and proposes that they get married. Helen accepts and goes away to live with Peter, 
leaving Jo alone. Jo has a fling with a black naval rating, Jimmie, who proposes to her, but leaves with his ship before he has time to make good on his promise. Jo discovers that she is pregnant, and a gay art student, Geof, moves in with her. At the end of the play Helen comes back and kicks Geof out. When she learns that Jo's baby will be black, Helen rushes out of the house, explaining vaguely that she is going out for a drink, and leaving Jo - who has just gone into labour - on her own once again.

\section{Talking to the Audience}

The cast cut the play heavily, occasionally rewriting portions during rehearsals - which was standard procedure at Theatre Workshop. At some point in rehearsal, the actor Avis Bunnage, who played Helen, began talking to the audience as if she were in a music-hall production. Bunnage was an experienced music-hall and revue performer as well as a 'straight' actor, and in our interview Murray Melvin (who played Geof) told me that only Bunnage was allowed to address the audience directly, though he said he was able to get one line in and was never rebuked for it. Melvin explained: 'Avis could do it because she had the experience - she just did it so wonderfully she stopped us doing it.' By contrast, when Theatre Workshop revived Brendan Behan's The Hostage later in the year, everyone in the company addressed the audience. This may have been inspired by the success of Avis Bunnage's experiment in $A$ Taste of Honey.

For Jack Reading, who attended the first night of $A$ Taste of Honey, this break in the fourth wall was a revelation. 'It was eyeopening to me what she did,' he told me.

She started the movement of the direct aside, which was particularly noticeable with the part of the mother, that she spoke directly to the audience. Not in the way that other plays were written for an actor to speak to the audience, where a man sits onstage and talks to the audience, that's rather different. Joan did it as part of the ordinary dialogue onstage. They would suddenly stop and say something direct to the audience. It was entirely novel to me, this wonderful idea of not doing this sort of aside [curling his hand over his mouth and tilted his head to the side] and all this nonsense, they just said it and moved on.

The 'direct aside' in A Taste of Honey was not so much an innovation as an appropriation from the 'illegitimate theatre' - notably music hall and variety theatre - where the fashion for 'naturalism' had never been established. ${ }^{9}$ As Jane Moody states in her book on illegitimate theatre in the late Georgian period, the term 'illegitimate theatre', at its simplest 'refers to the performances staged at those theatres where legitimate drama (tragedy and comedy) was prohibited'. ${ }^{10}$ Applied to the 1950s, a distinction between 'legitimate' and 'illegitimate' theatres can be drawn between theatres and companies (such as Theatre Workshop) which were subject to censorship by the Lord Chamberlain and theatres (such as those that put on music-hall and variety shows) which were not censored.

In Moody's view, the boundaries between legitimate and illegitimate theatre are permeated by appropriation in both directions. She cites Roger Chartier's observation that 'the appropriation of cultural objects by different social groups complicates and indeed undermines any dichotomy between elite and popular cultures'.11 Furthering this theme later in her book, Moody argues that 'illegitimate theatre was never respectful of social and aesthetic distinctions, nor indeed of cultural ownership'. ${ }^{12}$ This claim implies that illegitimate theatre does not respect its own classification.

Therefore, while superficially in A Taste of Honey illegitimate theatre is subsumed into the legitimate theatre, aesthetically the commingling of genres turns the entire enterprise illegitimate. But whatever the production's cultural antecedents, the critical attention and the audiences that it attracted were predominantly 'legitimate' - a tension between a play's construction and its reception which continued to be felt in the company's work.

\section{The Role of Jazz}

According to Joan's Book, Littlewood introduced the Apex Jazz Trio into A Taste of Honey in order to 'link the scenes and set the mood"13 


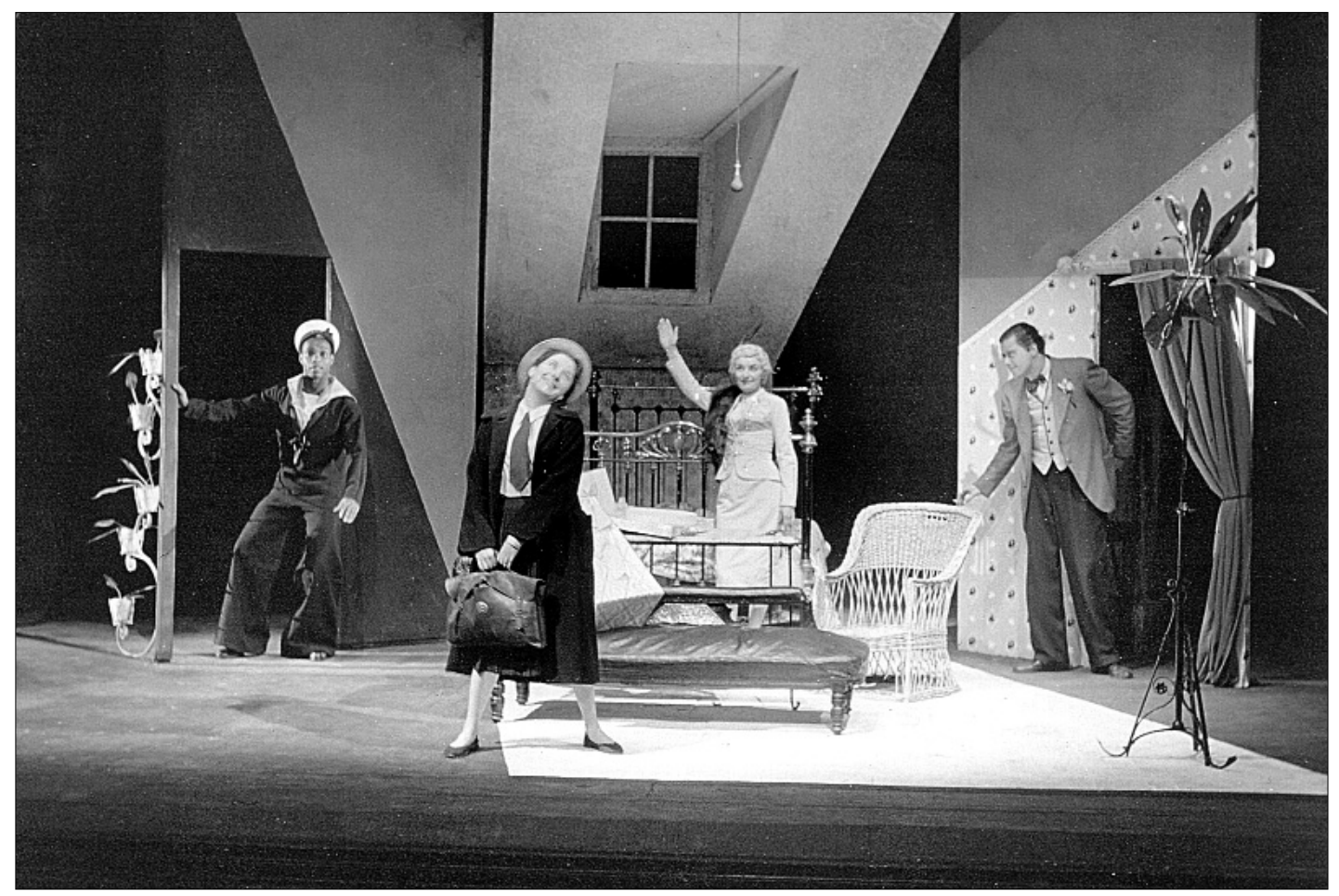

Scene from the Theatre Workshop production of $A$ Taste of Honey (1959). Photo courtesy of Theatre Royal, Stratford East, Archives Collection.

- although, as John Wallbank pointed out to $m e$, in the 1950 os 'there was no tradition of jazz in Manchester'. The original band consisted of Wallbank on trumpet, Olaf Luinberg on guitar, and Keith Phillips doubling on drums and saxophone. In our interview, Wallbank explained how the band came to be involved in the show. He was carrying out his National Service at the time, playing in a military band in London, and he belonged to an amateur theatre group run by Margaret Barrie, who was closely tied to Theatre Workshop, and later that year appeared in The Hostage. Wallbank told me:

Gerry Raffles phoned us and said, 'Will you form a band for the show?' So we went along and we played a few tunes for them, and Joan said, 'That's just what I want!' We only had a line-up of cornet, and guitar, and Phil, who played drums and saxophone. No bass. When we went to the West End there was just me - they were called up for National Service and couldn't do it. So I did it, and we had a bass player, and we had a guitarist. It was smoother. Joan never liked it as much. I think she liked the sharp roughhouse element of the music that was there before. She liked the way it cut across the abrupt changes of scene, so then people could dance into the next scene.

The band took the name 'Apex Jazz Trio' from the Jimmy Noone song 'Apex Blues'. The band played traditional New Orleansstyle jazz, heavily influenced by Louis Armstrong. In his essay, 'A Taste of Honey as Serious Text: a Semiotic Reading', Edward J. Esche has suggested that somebody should undertake 'a study of the first musical score' of the Theatre Workshop's production of $A$ Taste of Honey. ${ }^{14}$ In fact, no such score exists, though a list of songs can be cobbled together from a few sources. In Joan's Book, Littlewood writes that the band played 'Everybody Loves My Baby', 'Careless Love', 'Dippermouth Blues', and 'Baby Doll'. ${ }^{15}$ John Wallbank told me that the set designer, John Bury, also recalled the band playing 'Careless Love'. ${ }^{16}$ 'I don't remember playing it,' Wallbank added, 'but that's what he told me last week' - which only emphasizes how difficult it is to reconstruct the play's score. Wallbank explains: 
We always opened the show with a very fast $\mathrm{B}^{b}$ twelve-bar blues - it was never written down ... Then the other bright tune we played was 'Everybody Loves My Baby' by Spencer Williams or sometimes we played 'I Found a New Baby' [also by Spencer Williams] - they're very similar harmonically. We'd change whenever we got bored of one, and nobody seemed to mind much whether we changed it or not.

When I pressed him, he admitted that once the music was set, the band 'didn't change it that much'. In addition to the jazz, Wallbank says, 'there was some recorded music in it as well. When they come back from the fair, she's got a bunch of balloons and there's some sort of fairgroundy music, barrel-organ music sort of stuff just at the beginning of it.'

In addition to instrumental and recorded music, every character sings at some point in the play. In some instances lyrics are printed in the script, but other stage directions are more vague. A characteristic stage direction describes the end of the first scene between Jo and her sailor-boyfriend:

He waves goodbye, turns and sings to the audience, and goes. HELEN dances on to the music, lies down and reads an evening paper. Jo dances on dreamily. ${ }^{17}$

Wallbank told me he believes the music 'contributed a lot to the pace of the show. Instead of just having scene changes where people had to go off you could have a bit of music.' He added: 'I don't remember Joan ever doing it like that again, and when they made the film the music was terribly syrupy.' Wallbank also claimed that composer John Addison borrowed one of the songs the band wrote for the show, the 'Black Boy Theme'. The film score is heavily based on children's songs, which also occur in the play. Frances Cuka recalls that one song, 'The big ship sailed down the alley-alley-oh', was sung backstage by Avis Bunnage and the wardrobe mistress. ${ }^{18}$

\section{Breaching the Proscenium}

Joan Littlewood used the band as a visual element in the show as well as a musical element, but instead of putting them onstage, she had them play in one of the ornate boxes beside the stage. Melvin explained to me that this was another way of transgressing the invisible barrier enforced by the proscenium arch. He told me:

By putting the three boys in the box, it broke through the convention. They were there [indicating a box to the left of the stage] so your eyes went to the boys playing. You went out of the proscenium arch, there to the boys, and then came back as we came on.

The effect was especially strong because the actors on stage interacted with the band, which was in the audience. So the band brought the show into the audience, and then the actors and band openly communicated, thoroughly destroying the illusion of 'reality' as defined by the naturalistic theatre of the time.

Frances Cuka (who played Jo) told me that during rehearsals the cast decided to acknowledge the band. And so, she said, during the show all the performers 'acknowledged the boys in the box'. One example of this interaction was a dance Murray Melvin performed with a mop at the beginning of Act Two, Scene Two. When I asked Melvin about it, he told me:

You looked at the boys, and you played along. And if they did a certain riff then you'd change, and you gave them a look saying, 'Ohh, you thought you'd caught me out but you hadn't!'

Not surprisingly, the former music-hall actor Avis Bunnage carried the interaction furthest. John Wallbank told me:

Avis Bunnage would quite wickedly say, 'Ohh, you got that note wrong!' Avis was a brilliant actress, but it was that relationship with the audience. People tend to turn it, if they're not careful, into something far more dramatic. It suddenly becomes a bit of serious theatre.

A Taste of Honey's transgressive denial of conventional realism presents an interesting paradox: The performers routinely undermined the 'realism' of the fourth wall and the generic integrity of naturalist theatre during the show, and yet the play is clearly a socially realist, if not formally realist work. Melvin invoked the word when he told me that 'the play was ... 
more real' compared with Tony Richardson's naturalistic film version. John Wallbank expanded on this idea while he was telling me about the actor John Bay, who played Helen's boyfriend Peter in the original production. He told me that Bay

was un-'theatrical' in an artificial sense. He wasn't full of mannerisms and little tricks of the trade. Joan just didn't work that way. It was naturalism, but it wasn't a naturalistic production in any way. We had the music-hall bits, but they were all played for the truth of the thing.

Essentially, Wallbank is decribing the promotion of a realist end by non-realistic means. Brecht addresses the difference between socalled 'realism' and reality in his essay 'The Popular and the Realistic'. He writes:

One cannot decide whether a work is realistic or not by finding out whether it resembles existing, reputedly realist works which must be counted realist for their time. In each individual case the picture given of life must be compared, not with another picture, but with the actual life portrayed. ${ }^{19}$

In Britain in the 1950s, the 'reputedly realistic' style that Littlewood was subverting was the naturalistic convention whereby actors behave as if they are not being observed by an audience. The playwright Peter Nichols describes naturalism as 'a purgative reform that became an inflexible genre', adding that 'a direct appeal, an aside, any breach of the two-way mirror was seen as a sign that the playwright didn't know his job' ${ }^{20}$

Nichols himself used a jazz band in his first play, A Day in the Death of Joe Egg (1967). When I spoke with Joe Melia, who played the lead in Joe Egg, he told me that the band was on stage with the actors in the original production at the Glasgow Citizens' Theatre, and his character would occasionally stroll over and chat to them during the show - as well as sometimes chatting with the audience. When the production transferred to London, a smaller stage meant that the band needed to move to a box next to the stage, exactly like the band in Taste of Honey.

Like Avis Bunnage, Joe Melia had worked in revues and variety theatre, and he took to Nichols's mixed style 'like a duck to water' ${ }^{21}$
Peter Nichols, like Joan Littlewood, is regarded as both a social realist and a formal experimenter. He is a significant and underrecognized inheritor of Theatre Workshop's transgressive style. Nichols calls naturalism 'a form ripe for television', and adds, 'that's what - in the 1950s - it became' ${ }^{22}$

Murray Melvin shares this assessment. He told me that in 1958, when the company was developing A Taste of Honey, 'We were going through a period when the television was king.' He says that Littlewood viewed this as a kind of challenge. Television is essentially a realistic medium with no means of communication between audience and performers. Theatre is not conducive to formal realism, and Melvin told me that the direct addresses in A Taste of Honey were 'Joan's answer to television'. He added, 'This was the one place where you could answer back.'

Brendan Behan's interruptions during performances of The Hostage (1958) pushed this idea to its extreme. According to both Melvin and Cuka, Littlewood loved it when he made them. Melvin told me:

That, for Joan, was theatre. She was almost trying to get back to that Elizabethan rapport between performer and audience who chucked oranges if they didn't like it, or screamed out. That's what Joan loved, and woe betide you if you couldn't cope. If somebody shouted something and you were thrown, and you didn't reply to it or react to it, oohhh, you got what for the next day.

When she saw such an unfortunate actor, Littlewood would ask why they weren't free enough or secure enough within themselves to respond to their hecklers.

\section{Appropriation or Juxtaposition?}

The interviews which I conducted for this paper suggest that Theatre Workshop deliberately and to an extent systematically ruptured the barrier between the legitimate and the illegitimate theatres, as well as the 'fourth wall' between the actors and the audience. For Littlewood, who identified her politics as 'anarchist', these were steps towards making the theatre a robustly egalitarian and collective enterprise. 
In hindsight, her policies as a director raise an uncomfortable question: how does this kind of innovation distinguish itself from the appropriation it is based on? It could be argued that by bringing jazz and varietyshow techniques into A Taste of Honey Littlewood was, however noble her intentions, merely exploiting existing forms by injecting them into mainstream theatre. One could say that juxtaposition is not in itself creative, just canny and opportunistic.

While I do not believe that this criticism can be entirely dismissed, I also believe that it should not be allowed to stem the flow of appropriation across genres which has been a source of much of the theatre's vitality, whatever its venue. As Clive Barker (who performed in Theatre Workshop in the 1950 S and 1960s) explains, 'What Joan did ... was to take themes, ideas, concepts, and bring them together to create the work that was right for that time. ${ }^{23}$

Theatre techniques never come out of nowhere, and both Theatre Workshop and Joan Littlewood's earlier companies must in turn be acknowledged for their influence on political theatre companies such as 7:84, Red Ladder, and Pip Simmons, as well as on Peter Nichols and subsequent playwrights, directors, and actors who have refused to respect the divisions between 'legitimate' and 'illegitimate' theatre, and between actors and audience. By tracing these strands of appropriation, we can continue to flesh out the genealogy of contemporary theatre.

There is a great deal of research still to be done on both Theatre Workshop and A Taste of Honey. While I have focused on the work done on the play by the Theatre Workshop company, it was the distinctive tone of Delaney's writing that first drew me to it: the flat declarative sentences, the sarcasm, the epigrammatic turns of phrase, the stubborn confidence that suddenly dives into selfdoubt. 'The best bits were hers,' Frances Cuka told me when I asked her about Theatre
Workshop's alterations to Delaney's script, and John Russell Taylor, who has compared both versions, agrees. ${ }^{24}$ Though I have largely 'taken as read' Delaney's script in this essay, it is important to remember that $A$ Taste of Honey was not entirely company-generated: the production sprang out of a unique voice in theatre, and one which remains too little regarded to this day.

\section{Notes and References}

1. Murray Melvin, personal interview, 6 January 2003. All Melvin quotes are from this interview.

2. Frances Cuka, personal interview, 7 January 2003.

All Cuka quotes are from this interview.

3. John Wallbank, personal interview, 29 March 2003. All Wallbank quotes are from this interview.

4. Jack Reading, personal interview, 14 December 2002. All Reading quotes are from this interview.

5. Howard Goorney, The Theatre Workshop Story (London: Eyre Methuen, 1981).

6. Joan Littlewood, Joan's Book (London: Methuen, 1994).

7. Goorney, p. 183.

8. A Taste of Honey, dir. Tony Richardson (BFI, 1961).

9. See, for example, Peter Davison, Contemporary Drama and the Popular Dramatic Tradition in England (Totowa, NJ: Barnes and Noble, 1982).

10. Jane Moody, Illegitimate Theatre in London, 17701840 (Cambridge: Cambridge University Press, 2000), p. 1.

11. Moody, p. 5.

12. Moody, p. 80

13. Littlewood, p. 518.

14. Edward J. Esche, 'A Taste of Honey as Serious Text: a Semiotic Reading', in The Death of The Playwright? Modern British Drama and Literary Theory, ed. Adrian Page (London: Macmillan, 1992), p. 67-81 (p. 79).

15. Littlewood, p. 518.

16. Wallbank identifies the song as 'Careless Love Blues'.

17. Shelagh Delaney, A Taste of Honey (London: Methuen, 1959), p. 26.

18. This may be the song indicated in Act Two, Scene One (p. 54): 'children are heard singing in the street', or it may be the song indicated on p. 57 or p. 85 .

19. Bertolt Brecht, 'The Popular and the Realistic', in Brecht on Theatre, ed. John Willett, 2nd edn (London: Methuen, 1974), p. 107-15 (p. 112).

20. Peter Nichols, 'Introduction: Casting the Audience', in Nichols, Plays: One (London: Methuen, 1991), p. xi-xiv (p. xii).

21. Joe Melia, personal interview, 6 March 2006

22. Nichols, p. xii.

23. Quoted in Goorney, p. 166

24. John Russell Taylor, Anger and After, and edn (London: Methuen, 1969), p. 122. 